\title{
PENGASUHAN ANAK USIA DINI BERPERSPEKTIF GENDER DALAM HUBUNGANNYA TERHADAP PEMILIHAN PERMAINAN DAN AKTIVITAS KEAGAMAAN UNTUK ANAK
}

\author{
Evi Muafiah, Muhammad Imaduddin, Wirawan Fadly, Amik \\ Soraya Nastiti \\ Institut Agama Islam Negeri Ponorogo, \\ Institut Agama Islam Negeri Kudus \\ muafiahevi@gmail.com
}

\section{ABSTRAK}

Penelitian ini bertujuan mengetahui pola pengasuhan yang terjadi di lembaga PAUD maupun dalam lingkungan keluarga serta hubungannya terhadap pemilihan permainan dan aktivitas keagamaan AUD. Metode penelitian yang digunakan adalah mixed methods dengan desain concurrent embedded. Penelitian dilaksanakan di eks-karesidenan Madiun dengan pemilihan sampel melalui purposive sampling pada data yang diperoleh menggunakan metode kualitatif dan random sampling pada data kuantitatif. Data tersebut dikumpulkan menggunakan angket, observasi, dan wawancara yang kemudian dianalisis berdasarkan karakteristiknya melalui deskriptif kualitatif dan statistik inferensial. Hasil penelitian menunjukkan tiga hal. Pertama, masyarakat telah responsif gender pada pengasuhan AUD dan cenderung bebas pada aspek stereotipe, subordinasi, dan marginalisasi. Kedua, pemahaman responsif gender dalam pemilihan pemainan yang dimiliki guru lebih baik daripada orang tua/pengasuh, sedangkan pemilihan aktivitas keagamaan tidak ada perbedaan; dan Ketiga adanya hubungan 
signifikan antara pola asuh dalam lingkungan keluarga dan lembaga PAUD terhadap pemilihan permainan, namun berbeda pada pemilihanaktivitas keagamaannya dimana hubungan signifikan hanya pada lingkungan keluarga.

Kata kunci: Pengasuhan Anak, Berperspektif Gender, Pemilihan Permainan, Aktivitas Keagamaan

\section{ABSTRACT}

This study aims to determine the pattern of care that occurs in early childhood institutions and in the family environment and its relationship to the selection of games and religious activities of the early childhood. The research method used is mixed methods with concurrent embedded design. The study was conducted in ex-residency of Madiun with sample selection through purposive sampling on data obtained using qualitative and random sampling method on quantitative data. The data were collected using questionnaires, observations, and interviews which were then analyzed based on their characteristics through qualitative descriptive and inferential statistics. The results of the study show some conclution. First, the community has been genderresponsive to the care of the early childhood and tends to be free of stereotyped, subordinated, and marginalized aspects, Second, the gender responsive understanding of teacher selection is better than the parent/caregiver, while the election of religious activity does not exist differences, and Third, a significant relationship between parenting patterns in the family environment and early childhood institutions on the selection of games, but different in the selection of religious activity where the relationship is significant only in the family environment.

Keywords: Childcare, Gender Perspective, Game Selection, Religious Activity 


\section{A. PENDAHULUAN}

Keberadaan anak dan orang tuanya berada dalam sebuah keluarga sebagai unit sosial terkecil di masyarakat. Namun keberadaan keluarga ini mempunyai pengaruh yang sangat besar bagi bangsa dan negara. Jika keluarga dapat menjalankan fungsinya dengan baik maka sangat dimungkinkan tumbuh generasi yang berkualitas dan dapat diandalkan. Sebaliknya jika keluarga tersebut tidak menjalankan fungsinya dengan baik maka generasi bermasalah akan menjadi beban sosial masyarakat. Hal inilah yang melatarbelakangi perlunya pengasuhan anak yang baik dan benar agar anak menjadi generasi yang berkualitas dan sesuai dengan harapan baik orang tuanya.

Pengasuhan anak akan memberikan hasil yang lebih baik jika ayah dan ibu menjalankan pengasuhan secara bersama. Kebersamaan tersebut disertai dengan sikap yang mendukung dan bertindak sebagai satu tim yang selalu bekerja sama dan tidak saling bertentangan, meskipun peran yang dilakukan berbeda. Rotenberg yang menyatakan bahwa ibu berperan membentuk keyakinan tentang pentingnya kepercayaan dan ayah berperan membentuk perilaku untuk mempercayai (Lestari, 2014: 64). Pengasuhan bersama ini akan membawa hasil yang baik jika dilakukan secara responsif gender, yaitu pengasuhan yang respon terhadap perbedaan aspirasi, kebutuhan dan pengalaman perempuan dan laki-laki yang tujuannya mewujudkan keadilan dan kesetaraan gender. Keadilan dan kesetaraan gender ini menghendaki sebuah relasi yang egaliter, demokratis dan terbuka, serta ditandai rasa hormat dan saling menyayangi antara yang tua dengan yang muda dan antara laki-laki dan perempuan sebagai anggota keluarga sehingga semua mendapatkan hak dasar sebagai manusia (Mufidah, 2013: 48). 
Anak usia dini atau anak masa awal adalah anak usia 0 tahun atau sejak lahir hingga 8 tahun. Hal ini sebagaimana batasan yang dipergunakan oleh The National Association for The Education of Young Children (NAEYC). Namun di Indonesia biasanya anak usia dini dibatasi hingga usia pra sekolah yaitu 0-6 tahun (Patmonodewo: 2000: 43). Anak pada usia ini sangat peka terhadap lingkungan sekitarnya. Apapun yang didengar, dilihat dan dialami pada masa usia dini ini akan terekam dengan baik.Masa usia dini merupakan masa peletak dasar atau pondasi awal bagi pertumbuhan dan perkembangan selanjutnya. Maka sebenarnya wajar bila kita harus lebih memperhatikan pengasuhan bagi anak di usia tersebut. Diyakini oleh sebagian besar pakar pendidikan bahwa masa anak-anak yang bahagia merupakan dasar keberhasilan di masa mendatang (Nurani dkk, 2010: 21).Agar pertumbuhan dan perkembangan tercapai secara optimal maka dibutuhkan situasi dan kondisi yang kondusif pada saat memberikan stimulasi dan upaya pengasuhan yang sesuai dengan tumbuh kembang anak. Rentang usia tersebut juga dianggap sangat penting hingga sering disebut sebagai usia emas (golden age), yaitu saat perkembangan otak manusia mencapai 50\%-80\% dari keseluruhan perkembangan usia selama hidupnya (Mariyana dkk, 2010: 11). Penelitian tentang perkembangan otak menunjukkan bahwa otak berkembang lebih cepat dalam tiga tahun pertama kehidupan. Otak dapat dirangsang untuk berkembang. Anak-anak yang tidak memiliki lingkungan stimulasi memiliki otak yang lebih kecil dari otak normal untuk usia mereka (Shonkoff \& Phillips, 2000).

Masa usia dini merupakan masa yang tepat untuk menerapkan pengasuhan yang responsif gender sebagai salah satu upaya untuk memutus mata rantai budaya bias gender sejak dini. Hal ini selaras dengan salah satu tuntutan 
terhadap dunia pendidikan saat ini, yaitu pembelajaran responsif gender yang dirancang dan dirumuskan dengan parameter keadilan dan kesetaraan gender terutama dilihat dari segi akses, partisipasi, kontrol dan perolehan manfaat (Dewi, 2013: 127). Bentuk pengasuhan anak usia dini berkaitan dengan proses interaksi antara orang tua atau pengasuh dalam arti lebih luas dan anak dalam mendukung perkembangan fisik, emosi, sosial, intelektual, dan spiritual (Direktorat Pembinaan Pendidikan Keluarga, 2014:3). Salah satu bentuk interaksi tersebut dapat dilihat pada permainan anak. Permainan merupakan hal penting yang digunakan untuk mengembangkan aspek kognitif, fisik, sosial dan emosi anak (Goldstein, 2012: 6).Selain permainan, aspek keagamaan juga merupakan bentuk penting pengasuhan anak untuk mengoptimalkan perkembangan spiritualnya. Hal ini dilakukan karena anak juga memiliki hak untuk beribadah menurut agama yang diyakini anak. Sehingga penanaman dan pengenalan aktivitas keagamaan dapat dibiasakan pada anak usia dini baik di lingkungan lembaga PAUD maupun rumah (Mufidah, 2013: 302).

Latar belakang pekerjaan sangat berpengaruh terhadap pola pengasuhan yang dilakukan orang tua terhadap anaknya. Besty, Rustiyarso, \& Rivaei (2013) menunjukkan model pola asuh yang diterapka keluarga petani Desa Mangat Baru, Kabupaten Sinntang adalah pola asuh permisif dan pola asuh demokratis. Pada pola asuh demokratis orang tua akan mendorang anak agar mandiri tetapi masih menetapkan batas-batas atas tindakan-tindakan anak. sedangkan pada pola asuh permisif, orangtua terlibat dalam kehidupan anak, tetapi menetapkan sedikit batas atau kendali terhadap anak. Selanjutnya, Tiurida \& Hidir (2015) menunjukkan pola pengasuhan pada pola pengasuhan anak pada keluarga buruh pemetik teh khususnya seorang ibu yang bekerja 
di Perusahaan Terbatas Perkebunan Nusantara VI Danau Kembar Desa Kayu Jao. Hasil penelitian menunjukan bahwa pola pengasuhan anak yang diterapkan oleh para ibu buruh pemetik teh cenderung otoriter. Hal tersebut terjadi dikarenakan ibu yang mengambil peran ganda dalam keluarga harus membagi waktu antara bekerja dengan mengasuh anak. Bekerjanya ibu di luar rumah membuat pengasuhan kepada anak lebih keras dan kaku.

Fenomena di lapangan menunjukkan bahwa orang tua yang mempunyai anak usia PAUD (3-6 tahun) dan sudah memasukkan anak tersebut ke lembaga PAUD merasa bahwa pengasuhan sudah diserahkan kepada guru di lembaga tersebut. Padahal keberadaan anak di sekolah hanya sekitar 3-5 jam dan sisanya anak akan selalu berada di rumah bersama keluarganya. Hal inilah yang melandasi dilakukannya penelitian ini dengan menghadirkan komponen keberadaan anak di rumah dan lembaga PAUD. Lingkungan rumah dan lembaga PAUD dirujuk sebagai komponen yang paling berperan dalam pengasuhan anak. Keduanya seharusnya memiliki hubungan yang erat terkait dengan upaya mengoptimalkan aspek perkembangan anak. Dengan demikian, penelitian ini mengarah pada fenomena hubungan antara lembaga PAUD dan orang tua anak dalam pengasuhan yang responsif gender.

Kajian ini memiliki tujuan untuk mengungkapkan pola asuh responsif gender di lembaga PAUD dan di rumah serta hubungannya dengan pemilihan permainan dan aktivitas keagamaan. Pemilihan permainan dan aktivitas keagamaan yang dilakukan oleh anak berkaitan dengan pemahaman pengasuh, yaitu orang tua atau orang yang bertanggung jawab mengasuh anak di rumah serta guru di lembaga PAUD. Permainan anak dan aktivitas keagamaan anak pada akhirnya diharapkan berkontribusi pada perkembangan anak usia dini secara fisik, sosial, 
psikologis, maupun spiritual. Dengan mengetahui hubungan dan keterkaitannya diharapkan dapat dijadikan rujukan dalam hal sinkronisasi pola pengasuhan responsif gender di lembaga PAUD dan di rumah. Dengan demikian, tumbuh kembang anak dapat lebih optimal baik secara fisik, sosial, psikologis, maupun pada tataran spiritual keagamaan. Pola asuh yang dimaksudkan dalam hal ini berkaitan dengan pemahaman dan praktik pemilahan permainan dan aktivitas keagamaan untuk anak.

Pendekatan penelitian pengasuhan responsif gender pada anak usia dini ini adalah mixed methods yang mengkolaborasikan penelitian kuantitatif yang hasilnya akan diperdalam dengan penelitian kualitatif. Metode ini berupaya untuk memperluas temuan-temuan yang diperoleh dari satu metode dengan penemuan-penemuan dari metode lainnya (Sugiyono, 2015: 537). Strategi dalam penelitian ini dapat dilakukan dengan cara memulai penelitian kuantitatif terlebih dahulu dengan menguji hubungan pengasuhan responsif gender dengan permainan dan aktivitas keagamaan anak, kemudian diikuti dengan metode kualitatif dengan mengeksplorasi sejumlah kasus dan individu. Eksplorasi tersebut digunakan untuk mendeskripsikan pola asuh responsif gender di lembaga PAUD dan dirumah.

Penelitian tentang pengasuhan responsif gender pada anak usia dini ini dilaksanakan di wilayah eks karesidenan Madiun, Jawa Timur, yaitu kabupaten Ngawi, kabupaten Madiun dan kabupaten Ponorogo. Lokasi tersebut dianggap sangat layak dipilih karena pekerjaan para orang tua anak bervariasi seperti mulai dari petani, pegawai negeri sipil, pedagang, pekerjaan di bidang kesehatan hingga buruh migran (TKW/TKI).Berdasarkan pertimbangan pada kekhasan adanya profesi orang tua anak sebagai buruh migran, maka lokasi penelitian dipilih pada area 
kabupaten Ponorogo yang merupakan kabupaten dengan peringkat ke-7 se-Indonesia dalam hal jumlah buruh migran, kabupaten Madiun pada peringkat ke-12, dan kabupaten Ngawi pada peringkat ke-14 (BNP2TKI, 2017: 6).Selanjutnya, dilakukan penyempitan jumlah sampel data pada area kecamatan dan desa pada masing-masing kabupaten berdasarkan kriteria yang telah ditentukan antara lain melihat jumlah orang tua yang tidak tinggal serumah dengan anaknya. Pada akhirnya dipilih lembaga PAUD yang didalamnya terdapat AUD dari buruh migran sebagai lokasi penggalian data kuantitatif dan kualitatif. Kemudian sampel penelitian ini ditentukan melalui metode random sampling dan purposive sampling.Random sampling digunakan untuk pengumpulan data pada penelitian kuantitatifsedangkan purposive samplingdilakukan untuk menentukan para informan setelah data yang diperoleh menggunakan metode kuantitatif dilakukan (Sudjana, 2003: 73). Sampel penelitian ini adalah orang yang mengasuh secara langsung AUD yang terdiri dari: guru PAUD, orang tua, ataupun orang yang diberikan tanggung jawab oleh orang tua anak untuk mengasuh.

Data kuantitatif berupa data mengenai pemahaman orang tua dan guru PAUD terhadap pola asuh yang responsif gender, permainan anak, serta aktivitas keagamaan untuk AUD diperoleh dengan angket survey pemahaman yang berisi aspek-aspek indikator yang telah dimunculkan pada definisi operasional menggunakan jenis angket semi terbuka. Sedangkan data kualitatif diperoleh melalui observasi dan dokumentasi kegiatan permainan anak dan aktivitas keagamaan anak hubungannya dengan keadilan gender. Selain itu dilakukan deep interview pada orang tua dan guru PAUD berkenaan dengan keseharian anak dan lingkungan sekitar anak. 


\section{B. PEMBAHASAN}

1. Pola Asuh Responsif Gender pada Anak Usia Dini

Pola asuh responsif gender berkaitan dengan pemahaman dalam menata (1) lingkungan fisik, (2) lingkungan sosial, internal dan eksternal, (3) pendidikan internal dan eksternal, (4) dialog dengan anak-anak, (5) suasana psikologis, (6) sosiobudaya, (7) perilaku yang ditampilkan pada saat terjadinya pertemuan dengan anak-anak, serta (8) kontrol terhadap perilaku anak-anak(Kementerian Pendidikan dan Kebudayaan, 2014). Pemahaman pola asuh responsif gender diungkap dengan instrumen PARG yang terdiri dari 48 item pernyataan dengan skor maksimal adalah 192. Didasarkan pada item yang diisi, responden dapat diklasifikasikan menjadi 4 kategori yaitu Sangat Responsif (SR), Responsif (R), Cukup Responsif (CR), dan Tidak Responsif (TR). Kategori CR dan TR dikatakan sebagai golongan responden yang belum sepenuhnya responsif, artinya masih memunculkan bias gender pada pengasuhannya. Katogori pemahamana tersebut didasarkan pada aspek bebas tidaknya pengasuhan dari komponen stereotipe, subordinasi, dan marginalisasi. Hasil yang diperoleh pada analisis responden baik guru, orang tua, maupun pengasuh yang dijaring di tiga area kabupaten dapat dilihat pada pola bagan yang ditunjukkan Gambar 1 berikut ini. 


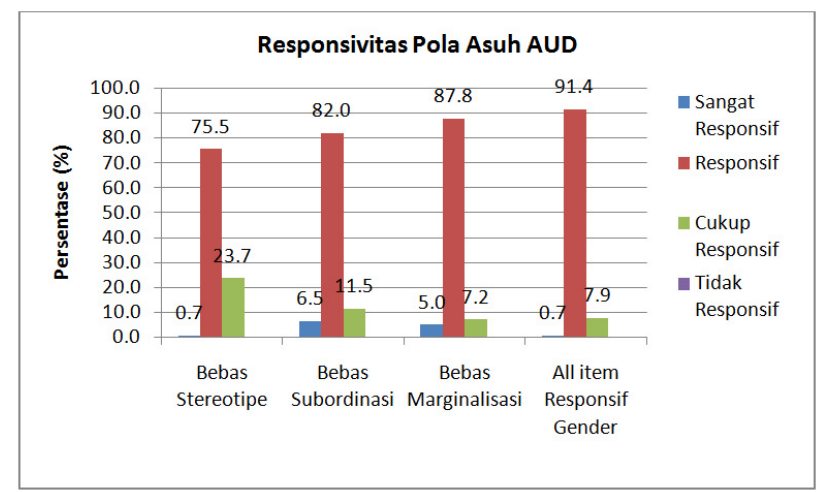

Gambar 1. Persentase ResponsivitasPola Asuh Anak Usia Dini $(\mathrm{N}=139)$

Pada gambar dapat dilihat kondisi responden pada aspek bebas stereotipe, bebas subordinasi, maupun bebas marginalisasi. Stereotipe yang dimaksudkan adalah pelabelan negatif, artinya ada cap yang diberikan kepada salah satu anggota keluarga AUD berkaitan dengan jenis kelaminnya (Kementerian Pendidikan dan Kebudayaan, 2014).Aspek bebas stereotipe, secara tidak langsung menunjukkan pemahaman responden untuk tidak atau meniadakan pelabelan negatif dalam pengasuhan anak. Penyebutan "label" negatif seperti: tidak pantas, kemayu, tidak pas, tidak cocok, atau penghakiman yang didasarkan pada aspek subjektivitas diri dan anggapan budaya yang berkembang di masyarakat adalah wujud stereotipe yang dimaksud. Kebijaksanaan guru dan orang tua atau pengasuh dalam melihat kondisi yang didasarkan pada aspek kebutuhan tumbuh kembang anak yang seharusnya dilihat, bukan pada aspek pandangan diri dan pandangan orang lain. Gambar 1. menunjukkan kondisi pemahaman terhadap aspek bebas stereotipe dalam pengasuhan menunjukkan perentase jumlah responden paling sedikit dibandingkan pada pemahaman aspek responsif gender. Hal ini memperlihatkan pelabelan 
negatif masih kerap muncul dalam pengasuhan. Hal yang paling terlihat didasarkan wawancara pada salah satu informan menunjukkan adanya rasa aneh dan ketidak pantasan jika anak laki-lakinya memakai baju warna pink ataupun memainkan boneka. Informan memperlihatkan ekspresinya dan menyatakan dengan pernyataaan "tidak pantas".

Beberapa penelitian menunjukkan bahwa anak lakilaki yang beraktivitas feminin dipandang lebih negatif daripada anak perempuan yang terlibat pada aktivitas maskulin (Feinman, 1981; Martin, 1990). Anak perempuan lebih bisa diterima dalam berperilaku cross-gender daripada anak laki-laki (Martin, 1990). Emulo (2014) menunjukkan bahwa stereotipe gender pada anak hampir bisa diamati mulai dari pewarnaan kamar tidur anak, pemilihan permainan, hingga jenis permainan anak.

Adapun aspek bebas subordinasi dimaksudkan pada kondisi pemahaman bahwa tidak ada lagi penomorduaan baik pada anak perempuan, maupun laki-laki dalam berbagai hal yang berkaitan dengan pengasuhan. Bapak, ibu dan anak-anak harus mempunyai peran yang adil dan seimbang, sesuai kemampuannya (Kementerian Pendidikan dan Kebudayaan, 2014). Anak laki-laki dan perempuan berada pada level yang sama pada setiap aspek pengasuhan. Hasil penjaringan data angket menunjukkan bahwa masih terdapat kecenderungan orang tua untuk membedakan level peran seorang anak. Sebagai contoh pernyataan, jika ada anak laki-laki dan perempuan yang seharusnya membantu ibu di dapur adalah perempuan. Hal ini menunjukkan ada kecenderungan pemberian peran pada anak perempuan untuk melaksanakan pekerjaan dapur. Dengan demikian, arah permainan anak yang berhubungan dengan peran koki atau masak-memasak lebih dipilih beberapa responden lebih sesuai dengan anak 
perempuan. Besty, Rustiyarso, \&Rivaei (2013) menunjukkan bahwa orang tua selalu menanamkan nilai-nilai keagamaan dan norma-norma yang berlaku di masayarakat dalam aktivitas pola asuhnya. Peran anak perempuan di dapur menunjukkan pola budaya yang berkembang di area responden dalam hal ini adalah masayarakat Jawa.

Selanjutnya, aspek bebas marginalisasi berkenaan dengan tidak adanya ungkapan atau upaya yang menyudutkan posisi anak baik perempuan ataupun lakilaki dalam hal penataan aspek-aspek pola asuh yang sudah tertera sebelumnya. Marginalisasi, artinya tidak ada anak yang disudutkan atau dipinggirkan. Semua anggota dalam keluarga perlu diberi kesempatan belajar, baik secara formal, non-formal dan tentu saja belajar secara informal dari orang tua. Beberapa pernyataan yang menyudutkan aktivitas anak adalah "hanya anak laki-laki yang cocok bermain panjat memanjat" serta "hanya anak perempuan saja yang boleh sering menangis. Anak laki-laki tidak boleh cengeng". Dari kedua pernyataan tersebut menunjukkan masihadanya penyudutan bagi anak didasarkan gendernya. Pengasuh baik orang tua maupun guru PAUD belum menyadari bahwa permainan adalah suatu bentuk proses pengembangan berbagai aspek sosial, kognitif, afektif, maupun psikomotorik pada anak. Penyudutan tersebut bisa jadi menjadikan anak terbatasi pada upayanya dalam mengembangkan aspek potensi dirinya.

Kondisi yang dapat terlihat bahwa pola yang terjadi memang sudah didominasi aspek kategori Responsi(91,4\%) yang menunjukkan bahwa masyarakat responden telah responsif gender pada pengasuhan anakusia dini. Meskipun demikian, masih muncul kategori Cukup Responsif(CR) yang menunjukkan belum sampai pada level responsif gender. Hal yang menarik adalah kategori CR didominasi pada aspek bebas stereotipe jika dibandingkan dengan 
kondisi bebas subordinasi dan bebas marginalisasi. Dengan demikian, dapat dirujuk bahwa pelabelan negatif pada anak usia dini masih dimungkinkan kerap muncul, daripada aspek penomorduaan (subordinasi) dan penyudutan anak (marginalisasi).

Sterotipe atau pelabelan negatif adalah pemberian citra baku atau cap kepada salah satu kelompok yang seringkali digunakan sebagai alasan untuk membenarkan suatu tindakan dari satu kelompok atas kelompok lainnya. Stereotipe yang terjadi pada pengasuhan AUD berhubungan dalam penataan objek lingkungan fisik yaitu pada pemilihan warna dan objek yang identik dengan labelisasi laki-laki atau perempuan, seperti warna merah muda atau pink hanya cocok bagi anak perempuan, sehingga jika dipakai oleh anak laki-laki menjadikannya tidak pantas. Aspek lingkungan sosial budaya juga kerap menggiring pada pelabelan seperti ketidakwajaran jika anak perempuan terlalu sering bermain di luar rumah. Pendidikan internal keluarga yang diberikan pada anak juga sering melabelinya misalnya ketidakpantasan anak laki-laki untuk membantu pekerjaan dapur. Selain itu, terkadang masih pula terjadi pelabelan negatif pada ekspresi anak akibat ketakutannya misalkan anak laki-laki tidak pantas jika takut terhadap sesuatu sehingga menjerit. Lebih lanjut, pola komunikasi antara orang tua dapat menjadi stereotipe contohnya dianggap tidak pantas jika anak perempuan dikerasi (diperlakukan tegas).

Kondisi pola asuh responsif gender diungkap berdasarkanskala pemahamanpolaasuhyangdiisiolehguru PAUD yang ada di area kabupaten Ponorogo, Madiun, dan Ngawi (N=11). Hasil yang diperoleh sebagaimana Gambar 2. Ditinjau dari gambar tersebut, kondisi pemahaman pola asuh guru didominasi oleh kategori responsif (R). Dengan demikian, sebagai pendidik AUD, guru telah mampu 
membebaskan diri dari aspek stereotipe, subordinasi, dan marginalisasi dalam mengasuh peserta didik.



Gambar 2. Pemahaman Pola Asuh Responsif Gender oleh Guru PAUD. $(\mathrm{N}=11)$

Kondisi pola asuh responsif gender diungkap berdasarkan skala pemahaman pola asuh yang diisi oleh orang tua atau pengasuh (kerabat atau pengasuh anak). Hasil yang diperoleh sebagaimana Gambar 3. Ditinjau dari gambar tersebut, diketahui bahwa kondisi pemahaman pola asuh didominasi oleh kategori responsif. Kondisi kategori CR dalam hal ini mengarah pada belum responnya terhadap gender masih juga muncul. Dengan demikian, secara umum pengasuhan AUD di rumah telah cenderung bebas pada aspek stereotipe, subordinasi, dan marginalisasi, meskipun masih ada pula pada beberapa area muncul ketidakresponsifan gender oleh orang tua atau pengasuh AUD.

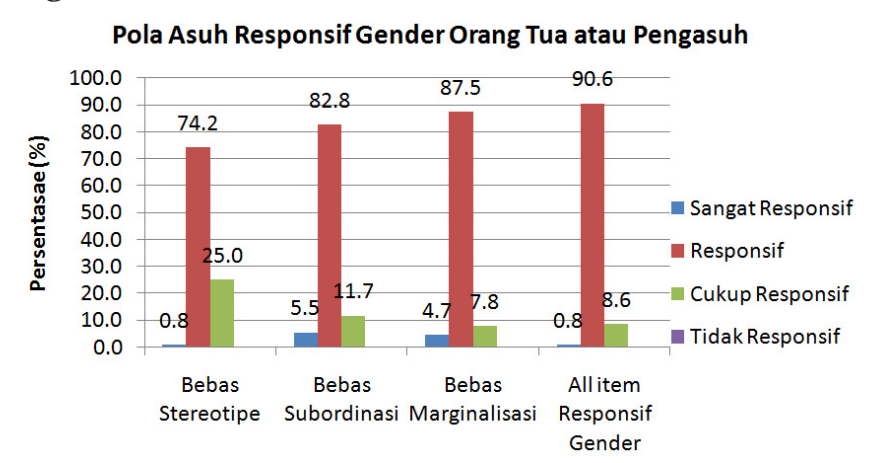


Gambar 3. Pemahaman Pola Asuh Responsif Gender oleh Orang Tua atau Pengasuh (N=128)

Di samping analisis melalui deskriptif kuantitatif juga dilakukan analisis melalui statistik inferensial untuk melihat perbedaan pola asuh anak usia dini di lembaga PAUD dan di rumah menggunakan uji-t test. Sebelum dilakukan ujittest dilakukan uji normalitas dan homogenitas. Dari hasil uji normalitas dapat diketahui bahwa nilai Sig. variabel $>0,05$. Dengan demikian, distribusi data pemahaman pola asuh responsif gender yang dimiliki oleh guru dan orang tua atau pengasuh berdistribusi normal. Pada uji homogentias menunjukkan bahwa signifikansi dari uji F didapat 0,225 atau artinya signifikansi $>0,05(0,225>$ $0,05)$. Dengan demikian, varians yang dimiliki oleh guru dan orang tua atau pengasuh anak adalah homogen atau sama. Dengan demikian dilakukan pengujian $t$ dengan menggunakan nilai "Equal variances assumed". Dari output diperoleh nilai $t_{\text {hitung }}=1,603$ sehingga nilai $t_{\text {hitung }}<t_{\text {tabel }}(1,603$ $<1,976)$, yang artinya bahwa tidak adaperbedaan rata-rata pemahaman pola asuh responsif gender yang dimiliki oleh guru dan orang tua atau pengasuh.

\section{Pemilihan Permainan Responsif Gender bagi Anak Usia Dini}

Pada dasarnya, dunia anak adalah dunia bermain. Bahkan bermain lebih penting dari pada belajar, sehingga pada masa anak-anak mereka dikenalkan belajar melalui permainan. Hal ini sebagaimana yang dikemukakan oleh Plato bahwa mengajarkan aritmatika kepada anak akan lebih mudah dilakukan dengan cara membagikan apel dan alat permainan miniatur balok. Sedangkan Aristoteles berpendapat bahwa anak harus didorong untuk bermain dengan sesuatu yang menjadi kegemarannya. Frobel 
bahkan menekankan pentingnya bermain dalam belajar atau belajar sambil bermain, karena kegiatan bermain maupun mainan yang dinikmati anak dapat digunakan sebagai alat pengembangan keilmuan anak tersebut (Tedjasaputra, 2001: 2).

Pada penelitian ini, permainan ditinjau pada jenis permainan fisik, permainan dengan objek, simbolik, sosiodramatik, dan permainan dengan aturan (Whitebread, Basilio, Kuvalja, \& Verma, 2012). Jenis permainan fisik yang disinggung berkaitan dengan permainan lompat tali, sepak bola, dan layang-layang. Jenis permainan dengan objek berkenaan dengan bagaimana sikap terhadap objek lumpur, cat air, hewan seperti cacing untuk dijadikan media dalam permainan. Simbolik berkaitan dengan seni yang mengarah pada gerak tari, musik, serta seni visual. Permainan sosiodramatik dihubungkan dengan permainan peran seperti peran dalam masak-masakan dan rumahrumahan. Adapun permainan denan aturan dicontohkan melalui permainan catur, bekelan, dan betengan.

Hasil tinjauan kategori respon gender dengan melihat dari masing-masing jenis permainan per area responden dapat dilihat pada Gambar 4. Dapat dilihat bahwa pada setiap jenis permainan, responden secara umum didominasi pada level responsif. Meskipun demikian, jika dilihat lebih detail pada kategori Cukup Responsif (CR) dan Tidak Responstif (TR) yang keduanya dikategorikan pada level belum responsif, jenis permainan fisik memiliki kecenderunggan untuk didominasi kategori CR dan TR jika dibandingkan dengan jenis permainan yang lain. Hal ini dapat dilihat secara jelas pada Gambar 4 yang menunjukkan persentase kategori keselurahan area. 


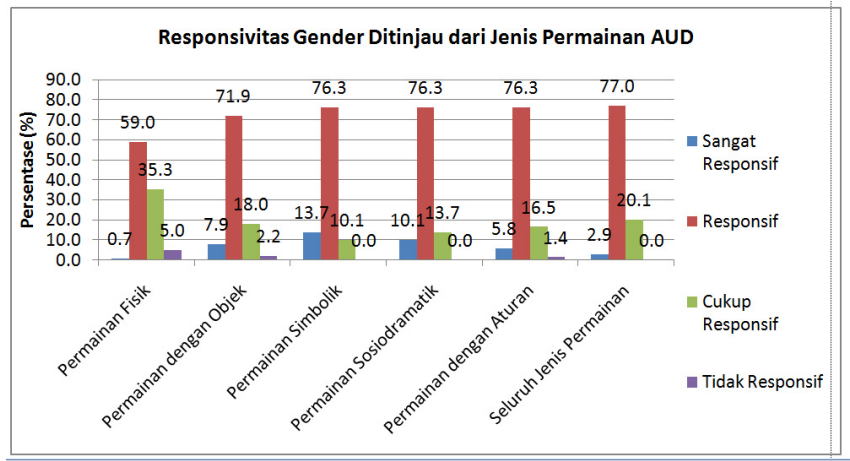

Gambar 4. Persentase Responsivitas Gender Ditinjau dari Jenis Permainan AUD. $(\mathrm{N}=139)$

Jika ditinjau dari kondisi komponen stereotipe, subordiasi, dan marginalisisi dapat digambarkan melalui Gambar 4 yang dapat diketahui bahwa responsivitas gender didominasi pada kategori sudah responsif ( $\mathrm{R}$ dan SR). Hal ini salah satunya disebabkan karena sebagian besar pemikiran orang tua masih diwarnai budaya masyarakat sekitar serta hal-hal yang pernah mereka alami sebelumnya pada masa kecilnya.Hasil wawancara dengan beberapa wali murid menyatakan bahwa mereka sangat jarang bahkan tidak pernah melihat anak laki-laki bermain bekelan atau bermain tali (semprengan). Dari hasil wawancara dengan salah satu wali siswa menyatakan bahwa tidak pernah menjumpai ada anak perempuan bermain sepak bola. Hal yang demikian ini juga dibenarkan oleh salah seorang guru yang mengatakan bahwa belum pernah melihat anak laki-laki bermain bekelan. Setelah ditanya oleh peneliti mengenai kecerdasan apa yang dapat ditanamkan pada permainan tersebut, barulah guru tersebut menyadari dan menyatakan bahwa akan menerapkan permainan apapun untuk menanamkan kecerdasan pada anak didiknya. Hubungan antara bermain dan belajar adalah kompleks, timbal balik, dan multidimensional. Proses bermain dan belajar merangsang satu sama lain pada anak usia dini - ada 
dimensi pembelajaran dalam bermain dan dimensi bermain dalam belajar. Bermain dan belajar adalah "dimensi yang tidak dapat dipisahkan dalam praktik pendidikan anak usia dini (Samuelsson \& Johansson, 2006).

Gambar 5. menunjukkan persentase responsivitas gender dalam pemilihan jenis permainan AUD. Dapat diketahui bahwa masih muncul kategori CR dan TR pada aspek stereotipe, subordinasi, dan marginalisasi. Responsivitas gender didominasi kategori "Responsif". Meskipun demikian, aspek stereotipe, subordinasi, dan marginalisasi masih muncul kategori Cukup Responsif dan Tidak Responsif.

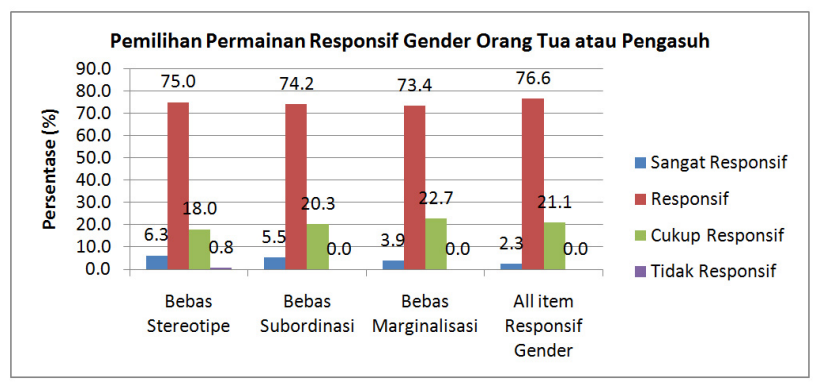

Gambar 5. Responsivitas Gender dalam Pemilihan Jenis Permainan di Rumah (N=128)

Selain itu dilakukan juga uji perbedaan pola asuh anak usia dini di lembaga PAUD dan Rumah diuji menggunakan uji t-test. Pengujian diawali dengan pengujian normalitas data. Dari hasil uji normalitas diperoleh hasil bahwa signifikansi dari uji $\mathrm{F}$ didapat 0,037. Dengan demikian signifikansi $<0,05(0,037<0,05)$, yang artinya varians yang dimiliki oleh guru dan orang tua atau pengasuh anak adalah berbeda. Dengan demikian dilakukan pengujian $t$ dengan menggunakan nilai "Equal variances not assumed". Dari output diperoleh nilai $t_{\text {hitung }}=2,247$. Dengan demikian, nilai $t_{\text {hitung }}>t_{\text {tabel }}(2,247>1,976)$. Hal ini menunjukkan bahwa ada 
perbedaan rata-rata pemilihan pemainan responsif gender yang dimiliki oleh guru dan orang tua atau pengasuh. Dari rata-rata dapat dilihat bahwa pemahaman responsif gender dalam pemilihan pemainan yang dimiliki oleh guru lebih baik daripada orang tua atau pengasuh.

\section{Pemilihan Aktivitas Keagamaan Responsif Gender bagi Anak Usia Dini}

Pada penelitian ini, pola asuh anak usia dini diungkap berdasarkan peran dominan pemahaman guru PAUD terhadap pemilihan aktivitas keagamaan yang bebas stereotipe, subordinasi, dan marginalisasi. Berdasarkan hasil yang diperoleh pada Gambar 6, dapat ditunjukkan bahwa hasil didominasi kategori "Responsif" untuk pemilihan aktivitas yang berkaitan dengan aqidah, syari'ah, dan mu'amalah. Pada gambar tersebut menunjukkan secara umum kondisi keseluruhan pembelajaran akidah, syari'ah, dan mu'amalah. Jika dibandingkan, pembelajaran aqidah sudah berada pada kategori sudah responsif ( $R$ dan SR) jika dibandingkan aspek pembelajaran syari'ah dan mu'amalah. Hal ini sebagian besar dikarenakan latar belakang sumber daya manusia orang tua atau pengasuh yang masih minim. Mayoritas mereka hanya lulusan sekolah dasar. Mereka masih beranggapan bahwa sebaiknya yang menjadi pemimpin di saat sekolah adalah anak laki-laki, meskipun mereka juga tahu bahwa ada beberapa perempuan yang sudah menjadi pejabat publik. Dari hasil wawancara dengan salah satu guru, mayoritas beranggapan bahwa perempuan hanya boleh bermain dengan perempuan apalagi pada masa sekarang ini dimana banyak terjadi salah pergaulan. 


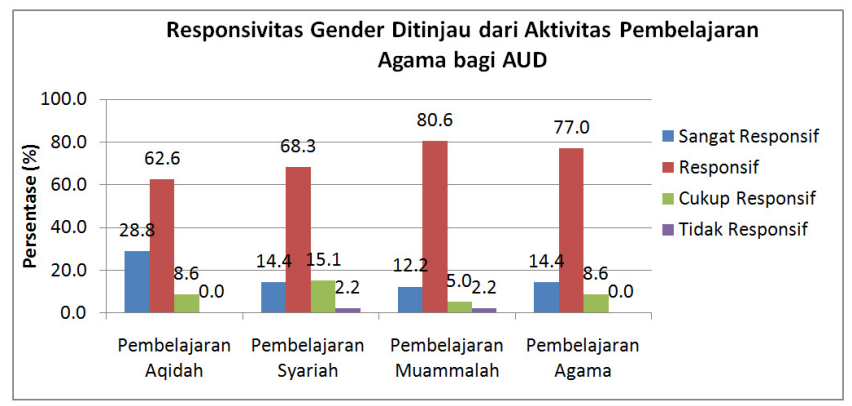

Gambar 6. Responsivitas Gender Ditinjau dari Aktivitas Pembelajaran bagi AUD

Jika dilihat dari aspek stereotipe, subordinasi, dan marginalisasi, dapat diketahui pola yang terjadi adalah adanya kecenderungan subordinasi yang dominan pada kategori belum responsif (CR dan TR) dibandingkan aspek yang lainnya. Hal ini berarti dalam pemilihan aktivitas keagamaan, masih muncul terjadinya penomorduaan pada anak baik. Sedangkan aktivitas keagamaan bagi anak usia dini ditinjau dari aspek stereotipe, subordinasi, dan marginalisasi dapat dilihat pada gambar 7 berikut ini.

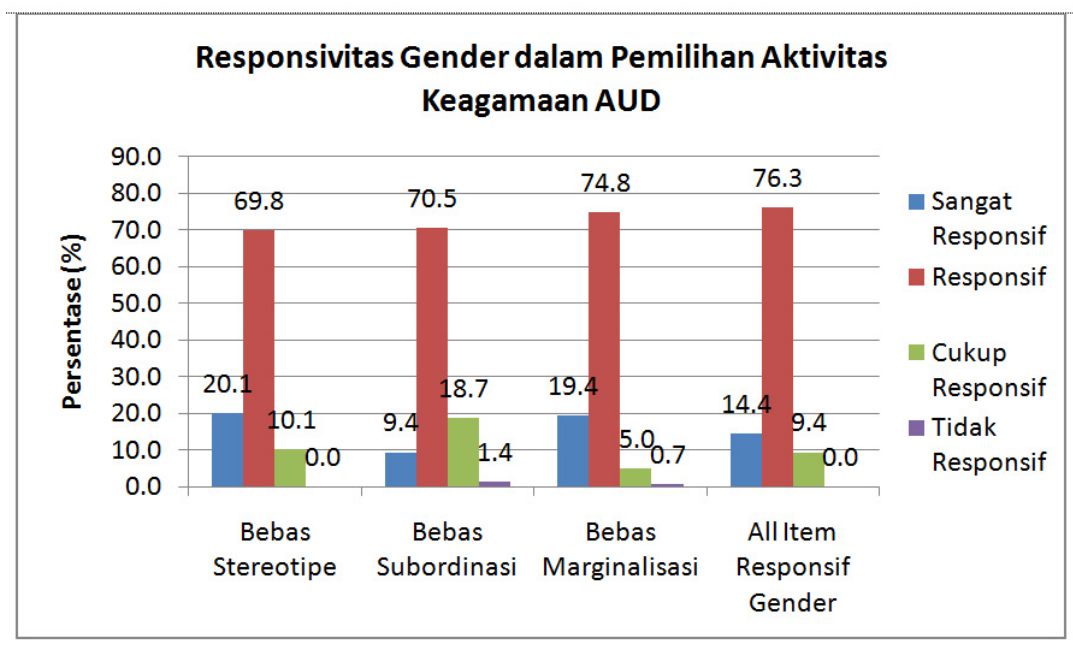


Gambar 7. Persentase Responsivitas Gender dalam Pemilihan Aktivitas Keagamaan Anak Usia Dini (N=139)

Gambar 7 memperlihatkan dominasi kategori "Responsif" pada keseluruhan aspek. Meskipun jika dilihat lebih lanjut, kondisi pada aspek subordinasi masih terdapat aspek belum responsif (CR dan TR). Hal ini memperlihatkan bahwa pada beberapa kegiatan keagamaan tertentu mereka masih membedakan perlakuan terhadap anak perempuan dan laki-laki. Diantaranya adalah mereka masih beranggapan bahwa anak perempuan tidak perlu diajari cara berniat menjadi imam shalat, dengan pertimbangan bahwa nantinya yang akan menjadi imam shalat adalah para laki-laki. Perlakuan yang berbeda juga tampak pada pembelajaran tentang cara buang hajat atau pipis, dimana lebih menekankan pipis dengan cara duduk bagi anak perempuan saja, sedangkan untuk anak laki-laki boleh dengan berdiri.

Dilihat dari pemilihan aktivitas keagamaan responsif gender di lembaga PAUD pada Gambar 8, menunjukkan bahwa kondisi pemilihan aktivitas keagamaan bagi anak usia dini oleh Guru PAUD pada kategori "Responsif". Seperti yang disajikan pada gambar berikut ini.

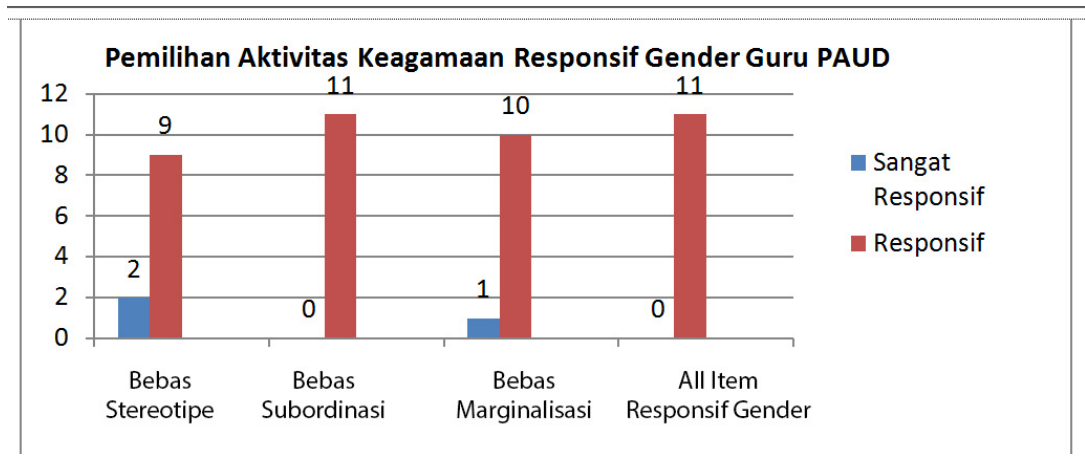

Gambar 8. Pemilihan Aktivitas Keagamaan Responsif Gender di Lembaga PAUD (N=11) 
Sedangkan pemilihanaktivitas kegamaan responsif gender di rumah yang ditunjukkan pada Gambar 9, menunjukkan bahwa kondisi pemilihan aktivitas keagamaan bagi anak usia dini di rumah pada kategori "Responsif". Dari Gambar 9. diketahui pula kondisi bahwa marginalisasi berada pada level paling responsif ( $\mathrm{R}$ dan SR) jika dibandingkan dengan aspek bebas stereotipe dan subordinasi. Dengan demikian, sikap menyudutkan atau pada akhirnya memberikan batasan dalam aktivitas keagamaan dimungkinkan sudah tidak terjadi lagi jika dibandingkan kemungkinan adanya pelabelan negatif dan penomorduaan. Seperti yang ditunjukkan pada Gambar 9 berikut ini.



Gambar 9. Pemilihan Aktivitas Keagamaan Responsif Gender di Rumah (N=128)

Pengujian statistik inferensial menggunakan uji t-test untuk melihat perbedaan pemilihan aktivitas keagamaan anak usia dini di lembaga PAUD dan di rumah. Pengujian diawali dengan pengujian normalitas data. Hasil pengujian normalitas ini dapat diketahui bahawa nilai Sig. kedua variabel $>0,05$. Dengan demikian, distribusi data pemilihan aktivitas keagamaan responsif gender yang dimiliki oleh guru dan orang tua atau pengasuh berdistribusi normal. Selanjutnya, data yang diperoleh dapat dianalisis dengan 
menggunakan statistika parametrik. Hasil menunjukkan bahwa signifikansi dari uji F didapat 0,037. Dengan demikian signifikansi $<0,05(0,048<0,05)$ maka dapat dikatatan bahwa varians yang dimiliki oleh guru dan orang tua atau pengasuh anak adalah berbeda. Berdasarkan hasil uji normalitas dan homogenitas maka dapat dilakukan pengujian $\mathrm{t}$ dengan menggunakan parametrik melalui "Equal variances not assumed". Dari output diperoleh nilai $\mathrm{t}_{\text {hitung }}=0,905$ dan hasil diperoleh untuk nilai $\mathrm{t}_{\text {tabel }}=1,976$. Dengan demikian, nilai $t_{\text {hitung }}<t_{\text {tabel }}(0,905<1,976)$, maka dapat dikatakan bahwa tidakada perbedaan rata-rata pemilihan aktivitas keagamaan responsif genderyang dimiliki oleh guru dan orang tua atau pengasuh.

\section{Hubungan Pola Asuh Anak yang Responsif Gender terhadap Pemilihan Permainan dan Aktivitas Keagamaan AUD}

Hubungan pola asuh anak yang responsif gender di lembaga PAUD terhadap pemilihan permainan dan aktivitas keagamaan anak usia dini diuji dengan menggunakan pengujian statistika. Pengujian diawali dengan melihat distribusi data pada aspek pemahaman pola asuh responsif gender, pemilihan permainan, serta pemilihan aktivitas keagamaan. Dari hasil yang didapat menunjukkan bahwa nilai Sig. ketiga variabel > 0,05 (0,199; $0,147 ; 0,200)$. Dengan demikian, distribusi data pola asuh responsif gender, pemilihan permainan responsif gender, serta pemilihan aktivitas keagamaan responsif gender adalah normal. Selanjutnya, data yang diperoleh dapat dianalisis dengan menggunakan statistika parametrik dengan menggunakan uji Korelasi Pearson.

Pengujian korelasi digunakan untuk mengetahui seberapa besar hubungan antara pemahaman pola asuh 
yang dimiliki oleh guru dalam memilih jenis permainan peserta didiknya, serta mengajarkan agama kepada anak usia dini. Hasil dari pengujian ditentukan kategori keeratan hubungannya. Selanjutnya, dianalisis signifikansinya dengan pengujian dua sisi (two tailed). Dari hasil analisis menggunakan SPSS dapat diketahui bahwa pemahaman pola asuh anak responsif gender yang dimiliki oleh guru berhubungan kuat $(0,772)$ dengan pemilihan permainan anak. Adapun hubungan antara pola asuh anak responsif gender berhubungan cukup kuat $(0,598)$ dengan pemilihan aktivitas keagamaan anak usia dini. Didasarkan output yang dihasilkan diperoleh signifikansi (Sig 2-tailed) hubungan antara pola pengasuhan dengan pemilihan permainan sebesar 0,005 $(<0,05)$. Dengan demikian, ada hubungan signifikan antarapola pengasuhan dengan pemilihan permainan di lembaga PAUD. Hewes (2006) menyatakan bahwa sistem pendidikan prasekolah cenderung menekankan manfaat bermain sebagai sarana untuk mencapai tujuan. Di dalam pendekatan komprehensif untuk mendorong pembelajaran melalui permainan, pendidik harus mengakui bahwa seluruh rangkaian dalam suatu permainan bernilai dalam proses memfasilitasi anak bermain secara spontan. Kesadaran pendidik tersebut terhadap proses pembelajaran anak usia dini melalui permainan menempatkan posisi pendidik menjadi lebih responsif gender.

Adapun hubungan antara pola pengasuhan dengan penanaman aktivitas keagamaan memiliki nilai signifikansi $>0,05(0,056)$. Dengan demikian, hubungan yang diperoleh tidak signifikan yang berarti tidak bisa digeneralkan untuk populasi. Pada sampel penelitian yang digunakan tidak terjadi hubungan signifikan. Pola komunikasi antara lembaga PAUD dan orang tua diharapkan dapat lebih intensif berkenaan dengan aktivitas keagamaan. Fauzia 
(2015) menunjukkan perlunya peran guru PAUD dalam membentuk perilaku keagamaan anak, serta dukungan orang tua dalam membentuk perilaku keagamaan pada anak usia dini. Keberhasilan lembaga pendidikan anak usia dini dalam membentuk perilaku keagamaan Islam pada anak ditunjukkan pada perubahan perilaku yang dialami anak, dan adanya kepercayaan terhadap sekolah. Dukungan orang tua terkait dengan pembentukan perilaku keagamaan Islam pada anak dapat berupa keikutsertaan orang tua dalam melatih pembentukan perilaku keagamaan Islam pada anak di rumah, serta kerja sama orang tua dengan pihak sekolah terjalin dengan baik.

Data secara kualitatif diperoleh bahwa di tiga lembaga PAUD yang menjadi lokasi penelitian sudah menerapkan berbagai macam permainan yang responsif gender. Meskipun ada juga beberapa permainan yang tidak diterapkan dikarena permainan tersebut dianggap tidak umum atau jarang dilakukan oleh anak-anak jaman sekarang. Sedangkan pada aspek penanaman aktivitas keagamaan, beberapa kegiatan sudah diterapkan, antara lain selalu berdoa sebelum melakukan kegiatan, melakukan latihan sholat berjamaah, menengok teman yang sedang sakit, bercerita tentang kisah para nabi, rasul dan para sahabatnya.

Hubungan pola asuh anak yang responsif gender di rumah terhadap pemilihan permainan dan aktivitas keagamaan anak usia dini diuji pula dengan menggunakan pengujian statistika. Pengujian diawali dengan melihat distribusi data pada aspek pemahaman pola asuh responsif gender, pemilihan permainan, serta pemilihan aktivitas keagamaan. Dari hasil analisa dapat diketahui bahwa nilai Sig. ketiga variabel $>0,05$. Dengan demikian, distribusi data pola asuh responsif gender dan pemilihan permainan responsif gender adalah tidak normal. Selanjutnya, data 
yang diperoleh dapat dianalisis dengan menggunakan statistika non parametrik.

Pengujian hubungan antara pemahaman pola asuh yang dimiliki oleh orang tua atau pengasuh dalam memilih jenis permainan AUD diuji dengan menggunakan uji Korelasi Pearson. Hasil dari pengujian ditentukan kategori keeratan hubungannya. Selanjutnya, dianalisis signifikansinya dengan pengujian dua sisi (two tailed). Dari analisis yang diperoleh dapat diketahui bahwa pemahaman pola asuh anak responsif gender yang dimiliki oleh orang tua atau pengasuh berhubungan kuat $(0,781)$ dengan pemilihan permainan anak. Didasarkan output yang dihasilkan, diperoleh signifikansi (Sig 2-tailed) hubungan antara pola pengasuhan dengan pemilihan permainan sebesar $0,000<0,05$. Dengan demikian, terdapat hubungan yang signifikan.

Selanjutnya, pengujian hubungan antara pola asuh responsif gender dengan pemilihan aktivitas keagamaan dilakukan dengan uji Korelasi Spearman karena data tidak berdistribusi normal. Dari hasil analisis statistik, dapat diketahui bahwa pemahaman pola asuh anak responsif gender yang dimiliki oleh orang tua atau pengasuh berhubungan kuat $(0,604)$ dengan penanaman aktivitas keagamaan. Didasarkan output yang dihasilkan diperoleh signifikansi (Sig 2-tailed) hubungan antara pola pengasuhan dengan penanaman aktivitas keagamaan sebesar $0,000<0,05$. Dengan demikian, hubungan yang diperoleh signifikan.

Pola asuh yang diterapkan orang tua biasanya didasarkan pada apa yang telah orang tua alami dan pelajari sebelumnya, baik secara sengaja di lembaga formal maupun apa yang sudah pernah dia dapatkan dari orang tuanya dahulu. Apa yang diperolehnya itulah yang kemudian juga dia terapkan pada anaknya. Hal ini 
terkadang juga diwarnai oleh pengalaman pribadi bahkan pengalaman kegagalannya. Seorang informan menyatakan bahwa sebenarnya dulu saat dia kecil tidak pernah diajari aktivitas di dapur karena dianggap dapur adalah arena bekerja perempuan. Namun pandangan itu sekarang menurutnya keliru atau berubah setelah dia mengalami sendiri bahwa laki-lakipun harus bisa mengerjakan pekerjaan yang berurusan dengan dapur yang selama ini dianggap sebagai pekerjaan perempuan.

\section{SIMPULAN}

Pola pengasuhan anak usia dini dalam penelitian ini menunjuk adanya kondisi yang responsif gender dengan variabel yang lebih dominan pada bebas stereotipe baik oleh orang tua maupun guru. Kondisi yang sama juga ditemukan dalam pemilihan jenis permainan dengan kondisi pemahaman responsif gender dimana guru memiliki pemahaman yang lebih baik dari pada orang tua atau pengasuh. Sementara dalam penanaman aktivitas keagamaan dalam pembelajaran aqidah, syariah, dan muamalah, terdapat kondisi belum responsif pada aspek sub ordinasi yang masih muncul. Pada beberapa kegiatan keagamaan tertentu mereka masih membedakan perlakuan terhadap anak perempuan dan laki-laki. Pola asuh anak yang responsif gender ini pada gilirannya berdampak pada pemilihan permainan dan aktivitas anak usia dini di Lembaga PAUD yang cukup responsif. Kondisi yang berbeda ditemukan dalam pengasuhan orang tua dan dampaknya pada aktivitas keagamaan dan pemilihan permainan di rumah yang menunjukkan masih adanya bias. Pengasuhan yang dilakukan orang tua sangat tergantung pada sumber daya manusia orang tua tersebut serta lingkungan masyarakat yang membesarkannya. 


\section{DAFTAR PUSTAKA}

Badan Nasional Penempatan dan Perlindungan Tenaga Kerja Indonesia (BNP2TKI), 2017, Data Penempatan dan Perlindungan TKI Periode Bulan Juni 2017, Jakarta: Pusat Penelitian Pengembangan dan Informasi.

Besty, D., Rustiyarso, R., \& Rivaei, W., 2013, “Pola Asuh Anak pada Keluarga Petani Desa Mangat Baru Kecamatan Dedai Kabupaten Sintang", dalam Jurnal Pendidikan dan Pembelajaran. Volume 2, Nomor 12: 1-15.

Dewi, S.M., 2013, “Pengembangan Model Pembelajaran Responsif Gender di PAUD Ainina Mejobo Kudus", dalam Jurnal Thufula PGRA STAIN Kudus, Volume 1, Nomor 1: 127.

Direktorat Pembinaan Pendidikan Keluarga, 2014, Seri Pendidikan Orang Tua: Pengasuhan Positif, Jakarta: DPPK.

Emulo, E., (2014). "Play, Toys and Gender Socialization", dalam Journal Plus Education, Volume 11, Nomor 2: 22-30.

Fauzia, S. N., (2015), Perilaku Keagamaan Islam pada Anak Usia Dini (Penelitian Kualitatif di Kelompok B TK Permata Sunnah, Banda Aceh Tahun 2015), dalam Jurnal Pendidikan Anak Usia Dini, Volume 9, Nomor 2: 303-318.

Feinman, S., (1981), "Why is cross-sex-role behavior more approved for girls than for boys?. A status characteristic approach, dalam Sex Role, Volume 7: 289-299. 
Goldstein, J,2012, “Play In Children's Development, Health And Well-Being", Brussels: Toys Industries of Europe.

Hewes, J., Early Childhood Learning Knowledge Centre., \& Canadian Council on Learning, 2006, "Let the children play: Nature's answer to early learning". Montreal, Que: Early Childhood Learning Knowledge Centre.

Kementerian Pendidikan dan Kebudayaan, 2014, Pengarusutamaan Gender Buku I: Panduan Pembinaan Keluarga yang Responsif Gender, Jakarta: Direktorat Jenderal Pendidikan Anak Usia Dini, Nonformal, dan Informal \& Direktorat Pembinaan Pendidikan Masyarakat.

Lestari, S, 2014, "Psikologi Keluarga", Jakarta: Kencana.

Mariyana, Nugraha, dan Rahmawati, 2010, "Pengelolaan Lingkungan Belajar", Jakarta: Kencana Perdana Media Group.

Martin, C. L., 1990, "Attitudes about children with nontraditional and traditional gender roles, dalam Sex Roles, Volume 22: 151-165.Mufidah, 2013,“Psikologi Keluarga Islam Berwawasan Gender", Malang: UIN Maliki Press.

Nurani, Y, dan Sujiono, B, 2010, “Bermain Kreatif Berbasis Kecerdasan Jamak", Jakarta: Indeks.

Patmonodewo, S, 2000, "Pendidikan Anak Prasekolah", Jakarta: Rineka Cipta.

Samuelsson, I.P., \& Johansson, E., 2006, Play and learninginsparable dimensions in preschool practice. Early Child Development and Care, Volume 1:47-65. 
Shonkoff, J.P. \& Phillips, D.A., 2000, “From Neurons to Neighborhoods: The Science of Early Childhood Development", Washington, D.C. National Academy Press.

Sudjana, N, 2013, "Tuntunan Penyusunan Karya Ilmiah", Bandung: Sinar Baru Algensindo.

Sugiyono, 2015, “Metode Penelitian Kombinasi”, Bandung: Alfabeta.

Tiurida, A. \& Hidir, A., 2015, "Pola Pengasuhan Anak pada Keluarga Buruh Perempuan Pemetik Teh PTP. Nusantara VI Danau Kembar Desa Kayu Jao Kecamatan Gunung Talang Kabupaten Solok, dalam Jurnal Online Mahasiswa Ilmu Sosial dan Ilmu Politik Universitas Riau, Volume 2, Nomor 2: 1-13.

Tedjasaputra, M.S., 2001, Bermain, Mainan dan Permainan, Jakarta: Gramedia.

Whitebread, D., Basilio, M., Kuvalja, M., \&Verma, M., 2012, "The Importance of Play", University of Cambridge: 18-24. 